\title{
Faithful Stewardship (Luke 16:1-15): An Important Part of the Solution to Corruption in Nigeria
}

\author{
*John Arierhi Ottuh \\ http://dx.doi.org/10.4314/ujah.v15i1.7
}

\section{Abstract}

The concept of faithfulness in the management of sacred and economic resources could be seen at the center of Jesus' parable in Luke 16:1-15. Although the parable could be seen as crux interpretum, it drove home the intended message in the conclusive part. While the kurios (master) and oikonomon (manager) were at the center of economic distribution and management, the masses were at their mercies for survival. Therefore, using evaluative model as a method, this paper aimed at the examination and evaluation of the Palestinian economic situation underlying Luke 16:1-16 as against the socio-economic situation in Nigeria and to apply the positive lessons learnt as part of the solution to the situation of corruption in Nigerian. The work showed that greed and dishonesty were seen in both the immediate (Palestinian) and contemporary (Nigerian) contextual milieus. All of these amounted to moral and economic corruption and it manifested itself mismanagement of resources. Luke 16:1-15 was reconstructed to anchor the lessons of proper management of cooperate resources, accountability, fidelity and honesty abhorring of greed for Nigerian leaders. This paper argued that imbibing the culture of faithful stewardship by Nigerian leaders at all spheres of leadership can help in the fight against corruption in 
Nigeria. This work was concluded on the presupposition that when all of these lessons learnt are applied in Nigeria, it will compel her political, traditional, civic and even religious leaders to be accountability conscious.

\section{Introduction}

The emphasis of faithful stewardship is long overdue in Nigeria. There are some traces of unfaithfulness in both sacred and secular leadership in Nigeria. No proper accountability to the people of Nigeria by political office holders. Although, some governors do organize town hall meetings in their states to give some shallow accounts of their governance to the people, resources expended on reported projects seems not to commensurate with what is empirically seen on ground by the ordinary citizens. Some times, some projects are not awarded according to the rule of law. Many average Nigerians do not know how much is entering and going out the national and state scoffers either monthly or annually. It is so because no law compels political leaders in Nigeria to give account to that effect.

In Nigeria today, over 2.4 million barrels of crude oil is being produced per day (Egbo 2010,3). Yet, large numbers of Nigerian population are living in abject poverty due to mismanagement of the nation's resources over the years. Corruption in both sacred and secular spheres of Nigeria has been identified as the destroyer of the nation's socio-economic and political lives. Our integrities seemed to be arousing questions and begging for answers in international socio-political, socio-cultural 
and socio-economic climes. The stigma of corruption is affecting the people of Nigeria in such way that when a Nigerian is passing through any international boarder, such Nigerian is given a very humiliating search. In some parts of the world, there are laws that compel political office holders to declare a true state of their assets before climbing the seat of authority but this is alien to Nigeria because we are yet to see any serious enactment and implementation of any law compelling Nigerian political office holders to declare their assets. This no doubt could have contributed to the difficulty being faced in investigating and ascertaining the true level of corruption among civil servants and political leaders. This is probably why court cases on corruption linger for too long in the court. Many whistle blowers cannot substantiate their claims of corruption against those they suspect because it is difficult for them to find enough information to back up their suspicions. All of these are happening in our political spheres because we have an irregular way of assessment of civic resources. This is why it becomes pertinent in our national live to promulgate and enact laws that will compel our political leaders in Nigeria to give account to the people as to how our financial resources came in and how they were spent. When this is put in place, it will become easier to detect corrupt leaders and prosecute them accordingly because as it stands today in Nigeria the average Nigerian in his or her innocent opinion believes that all political leaders are corrupt and that those being prosecuted for corruption are the unfortunate ones who are not in the good book of the person in the apex position of leadership. Should unfaithfulness and 
corruption continue in Nigeria? This question is indeed a propelling factor for the choice of this topic especially now that the cases of corruption is becoming more alarming by the day in Nigeria.

The aim of this paper, therefore, is to examine and evaluate the Palestinian economic situation underlying Luke 16:1-16 as against the socio-economic situation in Nigeria and apply the positive lessons learnt as part of the solution to the situation of corruption in Nigerian. To achieve this aim, the evaluative model is used as a method for this study. The evaluative model according to Ukong (2006:59) seeks to understand the biblical message against the background of African life, though and practice and also addresses situations that require changes in the society so as to move the society forward. By this understanding, the status of corruption in Nigeria is a situation that needs a change so that Nigeria can move forward as a nation.

\section{Conceptual Clarification}

Some times the word steward is misunderstood to mean a term of reproach and insinuates that the person called a steward is an ignoramus, a degraded person, an errand boy and a mere flunky. This understanding could have been reached due to certain lexicographers who have said that the word steward originally meant keeper of the pigsty, but the Oxford Dictionary of English Language refutes the above understanding by saying that it means a manager or an administrator. According to Dillard (1953,1-2), stewardship refers to the act of keeping or managing of the house, or act of overseeing of an estate, 
the act of one who employed servants, catered at banquets, a representative of the master of a business or the courts. Also according to the Complete Christian Dictionary for Home, School and Office $(2002,674)$ a steward is a person who serves on a large estate to manage domestic concerns such as collecting rent, handling accounts, directing servants. From the stand point of Luke 16:1-16, the term stewardship is oikonomia and it means governing, administration, the management of a household or of household affairs; specifically, the management, oversight, administration, of others' property; the office of a manager or overseer (Thayer, 2011). Generally, in the New Testament, two Greek words embody the meaning of the English word stewardship. The first word is epitropos which means manager, foreman, or steward. From the standpoint of government, it means governor or procurator. At times it was used in the New Testament to mean guardian (Galatians 4:1-2). The second word is oikonomos. It also means steward, manager, or administrator and occurs more frequently in the New Testament. Depending on the context, it is often translated "dispensation, stewardship, management, arrangement, administration, order, plan, or training." It refers mostly to the law or management of a household or of household affairs (Houdman, 2013).

Moreover, corruption is another concept that needs clarification in this paper. The Encarta Dictionary (2008) defined corruption as follows: dishonesty for personal gain or dishonest exploitation of power for personal gain; extreme immorality or depravity; an undesirable 
change in meaning or another error introduced into a text during copying; the corrupting of something or somebody, or the state of being corrupt; a word or phrase that has been altered from its original form; and rotting or putrefaction, or the state of being rotten or putrid. In the same line of thought, Brooks (1974:46) defines corruption as "the intentional mis-performance or neglect of a recognized duty, or the unwarranted exercise of power, with the motive of gaining some advantage more or less directly personal. Also, Alatas (1990:45) and Senturia (1993:33) see corruption as the abuse of trust for the sake of private benefits and the misuse of public power for private gains respectively. Ayobami $(2011,1)$ quoting Ruzindana (1999) says that corruption in Africa is a problem of routine deviation from established standards and norms by public officials and parties with whom they interact. He also identified the types of corruption in Africa as bribery, private gain, and other benefits to non-existent workers and pensioners (called ghost workers). The dishonest and illegal behavior exhibited especially by people in authority for their personal gain is corruption. According to the ICPC Act (section 2), corruption includes vices like bribery, fraud, and other related offences. Corruption can also be seen as the abuse or misuse of power or position of trust for personal or group benefit (monetary or otherwise). Corruption is a symptom of numerous difficulties within contemporary societies. It usually involves more than one party. It takes a form of an organized crime. At times, an organization can be established on corruption to beget corruption. Moreover Ayobami (2011:2) quoting Gbenga (2008) asserts that corruption is 
contagious. According to the perception index of Transparency International, Nigeria was ranked 144th out of the 146 countries, beating Bangladesh and Haiti to last position. From the above understandings of corruption, in the context of this paper it can mean impunity and the act of seeking power or opportunity to gather wealth through illegal means. It also means the gratification of inordinate desires.

\section{The Greek Version of Luke 16:1-15}

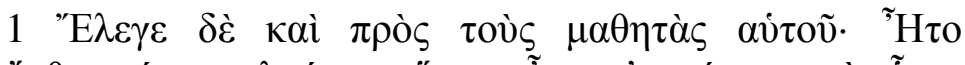

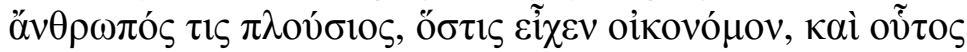

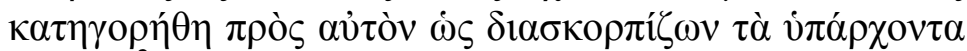

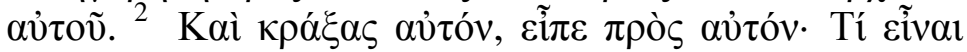

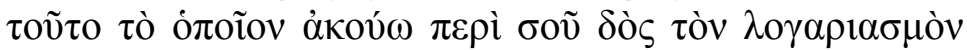

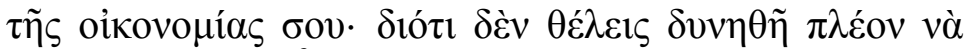

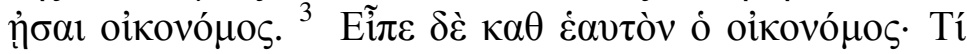

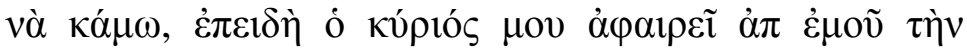

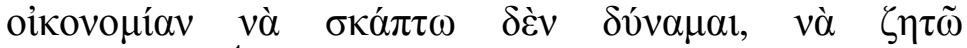

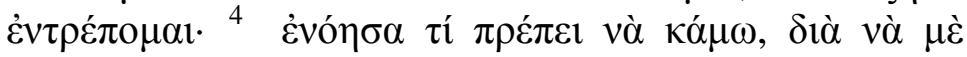

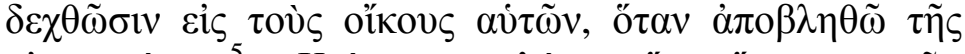

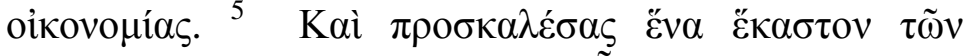

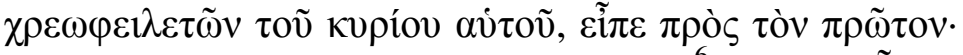

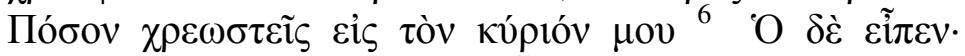

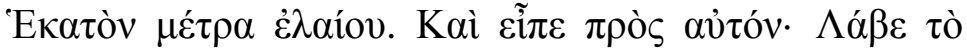

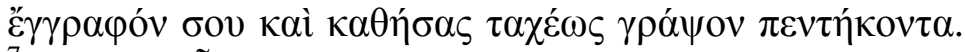

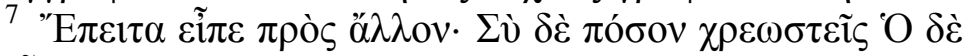

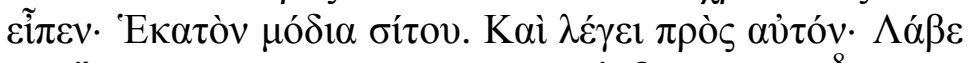

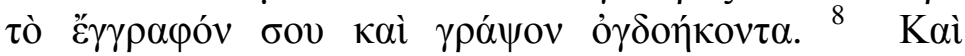

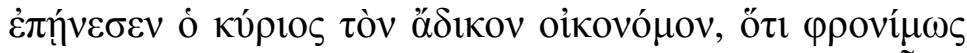

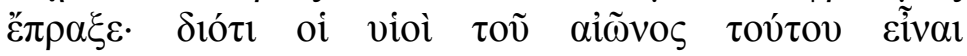

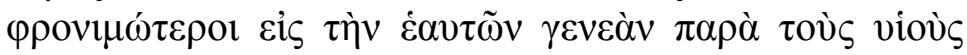




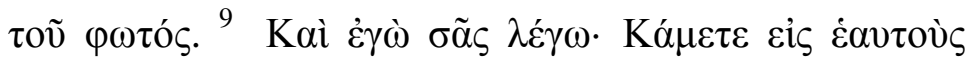

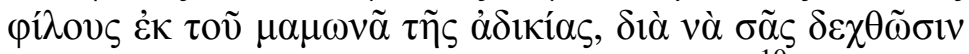

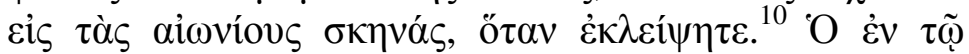

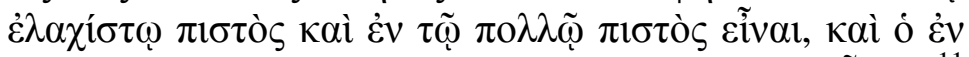

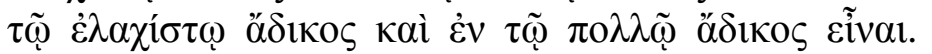

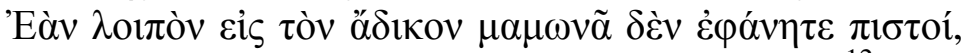

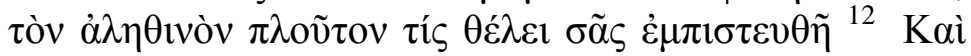

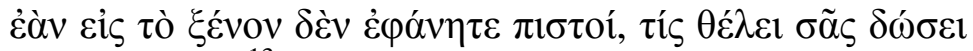

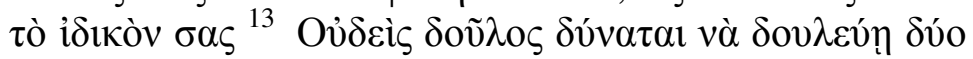

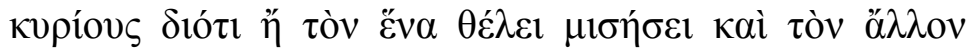

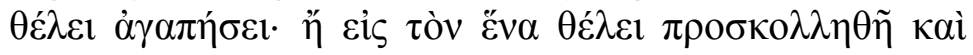

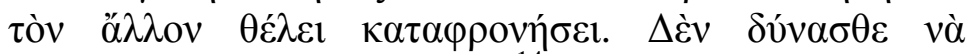

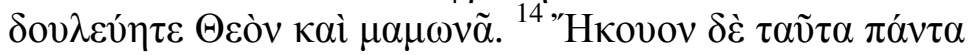

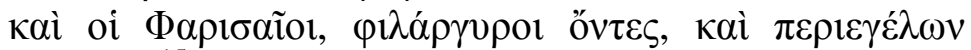

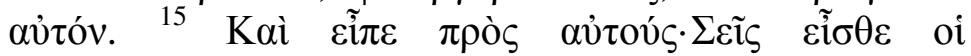

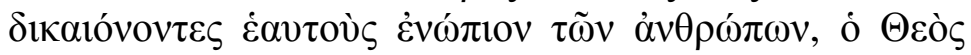

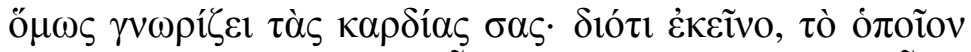

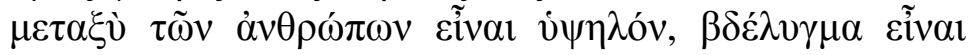

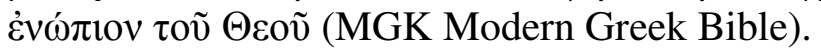

\section{The English Version of Luke 16:1-15}

$1 \mathrm{He}$ also said to the disciples, "There was a rich man who had a steward, and charges were brought to him that this man was wasting his goods. 2 And he called him and said to him, 'What is this that I hear about you? Turn in the account of your stewardship, for you can no longer be steward.' 3 And the steward said to himself, 'What shall I do, since my master is taking the stewardship away from me? I am not strong enough to dig, and I am ashamed to beg. 4 I have decided what to do, so that people may receive me into their houses when I am put out of the stewardship.' 5 So, summoning his master's 
debtors one by one, he said to the first, 'How much do you owe my master?' 6 He said, 'A hundred measures of oil.' And he said to him, 'Take your bill, and sit down quickly and write fifty.' 7 Then he said to another, 'And how much do you owe?' He said, 'A hundred measures of wheat.' He said to him, 'Take your bill, and write eighty.' 8 The master commended the dishonest steward for his shrewdness; for the sons of this world are more shrewd in dealing with their own generation than the sons of light. 9 And I tell you, make friends for yourselves by means of unrighteous mammon, so that when it fails they may receive you into the eternal habitations. 10 "He who is faithful in a very little is faithful also in much; and he who is dishonest in a very little is dishonest also in much. 11 If then you have not been faithful in the unrighteous mammon, who will entrust to you the true riches? 12 And if you have not been faithful in that which is another's, who will give you that which is your own? 13 No servant can serve two masters; for either he will hate the one and love the other, or he will be devoted to the one and despise the other. You cannot serve God and mammon." 14 The Pharisees, who were lovers of money, heard all this, and they scoffed at him. 15 But he said to them, "You are those who justify yourselves before men, but God knows your hearts; for what is exalted among men is an abomination in the sight of God (RSV,1952).

\section{The Situation of Corruption in Nigeria}

Corruption is present in Nigeria. The evidence is the persistent rising poverty rate and suffering of the people 
in the midst of wealth. In this same line of though, Faloore (2012) states that the rate of political corruption in Nigeria is progressively increasing with an upsurge in the number of cases where apparatus of government has become an instrument for the enrichment of members of political elites and that from preindependence era to date, political corruption and its attendant problems in forms of vote buying, election rigging and manipulation, outright embezzlement by politicians have negatively affected the lives of Nigerians. This has led to increased political apathy and distrust in the country's fledging democratic ideals. Oladele (2014) submits that political corruption remains the major challenge of governance in Nigeria and that political corruption negatively impacts other strata of governance such as security, education, energy and power and other sectors. It is reported by the former Chairman of the Economic and Financial Crime Commission (EFCC), Ribadu Nuhu, that Nigerian past leaders stole N64 trillion equivalent to US\$500 billion at the current exchange rates, from public coffers within a period of forty (40) years, and when this figure is benchmarked against the 2008 budget of N2.456 trillion, this translates into a budget of 26 years (Ukoni, 2010:15). Odey (2001:39-57) observed that some political leaders who gave the impression or promised to eradicate corruption are being seeing to be speaking with the two sides of the mouth. The state and National Houses of Assemblies are saddled with the responsibility of making laws and making sure that such laws are being faithfully implemented but it is amazing to see that some of those politicians who make the laws are the same people who break the laws. It appears institutions such as 
the Economic and Financial Crime Commission (EFCC), the Independent Corrupt Practices Commission (ICPC), etc are not well empowered enough to handle corruption in Nigeria. This is why it appears as if they cannot prosecute certain people in Nigeria.

In the civil service and judiciary, corruption is also domicile. One recent example is Mr. John Yusufu Yakubu, the former head of the Police Pension Board who was discovered to have embezzled N23.3 billion of the police pension fund and the most alarming situation is the laxity with which the court handled the case (Ugegbe and Onykwere, 22013: 1 and 6). He was given an options of two-year jail term or pay a fine of $\mathrm{N} 750,000$ of which he chose the option of N750,000 fine. People frowned at this judgment because it appears to be encouraging people to loot the nation. This and many other cases of corruption are going on in Nigeria.

Nigerian political leaders have planted and nurtured corruption. It has also spread to the civil service, church and the common people in the street. This is probably why Achebe (1983:37) sates that "Nigerians are corrupt because the system under which they live today makes corruption easy and profitable; they will cease to be corrupt when corruption is made difficult and inconvenient." That Nigeria is very rich and the majority of her citizens are living in abject poverty is indeed a paradox that beats the imagination of the entire humanity. The suffering of many Nigerians in the midst of wealth is a product of gross mismanagement of the nation's human and material resources by political 
leaders. The church in Nigeria cannot be exonerated from the issue of corruption in the sense that church leaderships have also been indicted of corruption in one way or the other. It has been observed that despite the emphases of the church on spirituality, the immense urge for the acquisition of economic prosperity by some church leaders could have been responsible for their financial misconducts (Apenda, 2006: 125). Obienyem (1999:46) as quoted in Gbenda (2006:117) observes that Christianity has been invaded by Church founders, pastor-impostors, pimps, plain thieves, wolves and worldly man. In the same vein, Iroegbu (1995:7) sees economic factor as the brain behind the multiplication of Churches today in Nigeria because our people are conjointly materialist. The excessive cravings for materialism by some contemporary church leaders in Nigeria no doubt is partly responsible for corruption in the Nigerian church. All of these can be classified under mismanagement of human and material resources.

These happenings in Nigeria have some resonance with the corrupt manager in Luke 16:1-16. One thing which the biblical (Palestinian) and the contemporary (Nigerian) milieus have in common in the passage in view is corruption. It is against this backdrop that Luke $16: 1-16$ is being interpreted in this paper.

\section{Literary Context of Luke 16:1-15}

The literary gentry of this passage falls within the gospel narrative. Luke used an allegory of management and accountability with the paradox of dishonesty and honesty to depict the greed men in this world. The audience was a mixed multitude comprising disciples 
and Pharisees. Generally, Luke's literary styles cover both Semitic and Hellenistic lingua pattern depending on his audience (Foster, 1995:1530). Being that the main audience of Luke is familiar with Hellenistic culture, the narrative, language and literary structure were in conformity to classical Hellenistic culture and business administration. The lesson was weaved in a parable. The parables of Jesus as preserved in the synoptic gospels represent the very oldest traditions in the New Testament. Parables might be quaint and poetic, but hardly relevant for Christian discipleship. Churches that do attend to the parables had to spiritualize them relentlessly, typically preaching them as earthly stories with heavenly meanings (Myers, 2012: 56). Stories about landless peasants and rich landowners, lords and slaves or helpers and lawyers are lifted out of their social and historical context and reshaped into folksy theological or moralistic fables bereft of any political or economic edge or consequence. But once the sociocultural context indigenous to the story has been ignored or suppressed, the story is easier to recontextualize in terms of another unconscious political assumption and as such, parables are by design irresistibly metaphorical in some senses (Myers 2012,57).

In this parable, Luke illustrated the kingdom with business and societal imageries precisely in order to emphasize that it was not a metaphysical scenario.' The genius of these stories as popular pedagogy was that they narrated recognizable scenarios such as farming (Mk.4:1-9), shepherding (Matt. 18:12-14), being in debt (Luke 7:41-43), doing hard labour (Matt. 20: 1-16) and 
dishonesty (Lk.16:1-15) in plain language that any illiterate peasant could understand (Myers 2012, 58). The parable in Luke 16:1-15 could be seen as portraying concern about economic justice. Luke 16 is neatly structured as; two parables with identical opening lines bracketing Jesus' teaching concerning mammon and the love of money. It is structured as follows in Myers $(2012,58)$ view:

16:1-8 there was a rich man who... (16: 1).

Parable of the unfaithful oikonomos (steward)

16: 9-13 Teaching on God and Mammon

16:14-18 Attack an Pharisees as lovers of money

16: 19-31 There was a rich man who ... (16:19)

Parable of Lazarus and the rich man

The whole chapter is clearly a literary unit, though also firmly linked to the previous and subsequent narrative.

The first parable has several links to the immediately preceding parable of the prodigal son (15:1-32), notably the fact that the later is also about a rescue by the household love economy and use of the verb diakopizon meaning wasting to depict redemption (15: 13; 16:1). The Lazarus parable in turn, anticipates Jesus' teaching about not causing little children to stumble (17:1-4). With the exception of the saying on divorce (Luke 16:16-8 = Matt. 5;18, 31-32, and Mark 10:11-12), this chapter has no parallel with the other synoptic gospels. Against the backdrop of literary embellishment some scholars called the parable, the crux interpretum among the parables and it portrays the problem child and puzzle of modern literary structure of exegesis (Julicher 1910, 495; Rucker 1912, 1; Stoll, 1941: 17; Lunt 1954, 335). 
Luke 16:1-16 is metaphorically and ironically structured within a Hellenistic literary narrative style. Looking at it from Luke's literary style of writing it is characterized by literary excellence, historical details and classical in Greek vocabulary (Foster 1995,1530).

\section{Socio-Economic Context of Luke 16:1-15}

In the Old Testament, the Law of restitution was enacted to deter people of the society from cheating on one another economically and morally as could be seen in Leviticus 6:1-7 (Harris and Youngblood 1995,152). The law states that if any one stole or cheated; such person was to return what was stolen along with additional $20 \%$ interest of the worth of stolen items. This could have formed the Old Testament background to Luke 16:1-15 because it addresses and encouraged stewards to be faithful in handling what is entrusted into his care (Lev.6:2).

Luke 16:1-15 is parabolic and eschatological in nature. In one sense, it is talking of the parousia and another sense, it is talking about the abilities of men to administer given resources to benefit humans for which God has made such resources available (Kehlenberger 1987,589). It is eschatological in the sense that just as earthly stewards under men are required to give account to their master, so will everyone give account before God at the consummation of time. A parallel reading is found in 2 Corinthians 5:10 of which Christ the kurios (lord) will be the judge and all men shall appear before for judgment at the consummation of the kingdom of God (basileia tou Theous) on earth. While the parable 
addressed the eschatological dimension in relation to the kingdom of God, the earthly politico-economic situation was depicted in the parable. Prior to and during the time of Jesus in Israel, the economic situation was understood to do with the management of the household, large estate or even the imperial realm (Oakman 2000,303-308). In the New Testament times, the Roman Empire was managed by the imperial powers as an extended household (Bailey 1993,293-299). Easy access to the Mediterranean Sea encouraged maritime trade in the Hellenistic-Roman periods, but this was controlled by elites or their agents (Bailey 1993,748-749). The Palestinian economy was an agrarian economy and as such it was a common place to see large land owners who are known to be power economic elites entrusting their vineyards or estates to someone to manage on their behalves and the manager gives account to the master whenever he comes around (Wessel and Lane 1995,1515).

What made the agricultural economy in Jesus' time included pastoral and crops farming and fishing. Farm owners through the aids of the manager employ labourers, pay on their behalves and also help in the sales of harvested produce from the estate (Oakman 2000,304-305). Being that in Jesus days the Israelites were under the control of the Roman power this parable like other parables of Jesus falls within the context of economic oppression and social disparity and concerns. The house of Herod the Great provided client rule for the Romans at the eras. Jesus parables often describe the typical social features of a colonial situation with large 
estates controlled by absentee landlords and as such a landlord's departure provided the occasion for money lending by retainers thereby making the estate manager to make frequent appearances as in the cases of Luke 12:42; 16:1-8; Mark 13:34-35. Many of these social features are common to agrarian or peasant societies like that of Luke's church community.

In relation to this parable Crossan (2002,252-253) citing Rohrbaugh describes the social-economic situation of Palestine in the time of Jesus thus:

in the peasant world of imposed limitation, with the ethic of family subsistence and village security rather than imperial exploitation and commercial wealth, one experienced rich people as inherently evil... because to have gained, to have accumulated more than one started with, is to have taken over the share of someone else. In that peasant morality, the first two servants would be exploiters who probably increased their master's money by loans and foreclosures ( of peasant farmers) and it would be the third servant who acted honourably and ethically by refusing to enter into such oppressive activity.

In the community where the parable was transmitted, most people in Palestine were poor. The society had a few self-sufficient people, but they belonged to the aristocracy. The overwhelming number of the people of Jesus' community were labourers, tenant farmers, and 
stewards (Crossan 2002,251). A few of them were traders. The elite such as landowner, priests and scribes engaged either directly or indirectly in business activities and in politics (Folarin 2006,24-29). They allied with the Roman authorities to protect their mutual interests at the expense of other members of the society. During this period, the priests and scribes provided theological justifications for the exploitation and oppression of the poor (Carter 2002, 261-262). Tax collectors inflated their taxes. Stewards increased the cost of their master's goods.

The sacred aspect of the society was not left out of the economic situation in the sense that the priests and rabbis controlled the business associated with the Temple and the revenues that came from the sale of animals for sacrifice, and the exchange of money from the temple tax. Some members of the Sanhedrin were probably landowners who rented out farms and profited by a share of the crops (Tenney 1961, 47-48). The social-economic situation in which Jesus told this parable benefited the small ruling elite. It was a system that concentrated wealth in a few hands, a society where the poor became poorer, and the rich became richer. Even though poor Jews hated exploiters, since financial profit was attached to being a rich man's steward, many accepted to serve rich people, and some even aligned with these exploiter (Folarin 2006). Luke 16:1-16 is situated in the above socio-economic background and such situation is not far fetched in Nigeria especially when we look at it from the view point of slave trade, western imperialism and corruption. 


\section{Analysis of Luke 16:1-15}

The parable that formed the pericope (Luke 16:1-15) is often referred to as the parable of the unjust or dishonest steward. This already biases one's reading and encoding of the hermeneutics of moralistic capitalism which takes the side of the boss in the story and vilifies the steward. However, the parable seems to see the master as commending the steward's shrewd action. It showed the story of a failing steward who knew that his master was about to sack him but cleverly covered up to make some money for his master. This is what this work refers to as unfaithful steward. This story could be recapped in the context of this work as "faithfulness in stewardship." The master in this parable could be seen here as the boss who required faithfulness from his steward no matter how he did it. Here Jesus could not be seen as someone condoling dishonesty but ironically advocating faithfulness in dealing with the business that is entrusted to one to manage on behalf of God and the people.

The parable tells us of a certain plousios anthropos (rich man or a person who is wealthy in resources-Luke 16:1a). The story begins with a matter-of -fact acknowledgement that the economic world in which Jesus told this parable was ruled by the absentee landlord class. Luke's Jesus has already made his attitude to the landed rich painfully clear in an earlier parable (Luke 12:16-21; antropou tinos plousiou-meaning a certain rich man), another story that radically contrasts severe economies. Like that farmer and his ever bigger bans, the estate implied here is vast and it is indicated by the significance of the amounts of wheat and oil owed by the 
antropou tinos plousiou meaning "the rich man" (Myers 2012,60). According to Herzog (1994, 240-241), in the calculation of the worth of the estate, the wheat and oil in it could be valued between one and three thousand denarii (one denarius was the average substance wage for a day's labour in the Greco-Roman world). In this line of thought, Bailey $(1983,92-93)$ opines that the debtors are sharecroppers working the estate. Also, Malina and Rohrbough (1992,375) say that the huge amount suggests that perhaps these are whole villages owing percentages of their harvest or perhaps merchant commodity traders competing to distribute produce to foreign markets (Herzog 1994,249-250).

Oikonomos (steward, house managers) and the kurios (lord master) are the two main characters in the storyline of the parable in Luke 16:1-16. Another ambiguous character apart from the rich man, his debtors and the manager are the common people in the milieu of the parable. Although, the passage did not tell us vividly about the common people, verse one suggests that some or some people accused the manager before the master that the manager was diaskorpizon uparchonta (wasting resources). The reporter or the accusers could probably be those people (ochlos) crowd of people or (anthropos) a person (Summers 1995, 15; 180). This scenario's characters formed a tripartite economic situation in Jesus' time; viz, the rich land owners, the middle class and the peasants. The society was full of greedy rich men who want to be richer at the expense of the poor. Lenski (2008, 243-244) called the oikonomos the dependent retainer class, which he described as officials, 
professional soldiers, household servants, and personal retainers, all of whom served the ruling class in a variety of more or less specialized capacities. This literate bureaucratic class had a tenuous existence: they had to ensure exorbitant profits for the kurios (master) through merciless resource extraction and labour exploitation, while at the same time maintaining working relations with peasant producers and competitive merchants. In this line of thought, Herzog $(1994,244)$ observed that such a manager was always caught in the crossfire between the master's greed and excessive demands, and the tenants or debtor's endless complains. This is where the analogy with modern middle-class, educated folks broadly applies like the oikonomos of the parable. The oikonomos is nevertheless subservient to an economic system that both benefits and victimizes us (Myers 2012, 60). In the milieu of this parable, both the kurios (master) and oikonomon (manager) belonged to the ruling and economic elites who are exploiting and using the resources of the people for their personal gain.

Furthermore, the verb diaskorpizon as used in the passage and elsewhere in Mark 14:27; Acts 5:37 and Matthew 25:24 referred to a physical or geographic scattering of people. In Luke 16:2 diaskorpizon uparchonta, mean wasting of resources especially economic resources. The manager, having heard of his Master's intention to sack him decided to device a means to get out of the trouble of diaskorpizon (wastage of resources). Though the manager's action is yet to be revealed, he is going to do whatever it takes to cross over from the economy of Gesellschaft (German, commonly translated society) to that of Gemeinschaft (German, 
commonly translated community) (Myers 2012,61). Although he was trying to cleverly scatter the wealth of his master by asking the master's chreopheileton (debtors) to pay less than they were owing him, he was dishonest. Therefore, both diaskorpizon (wasting or misuse of resources) and his shrewdness amounted to corruption (phtheiro). Although phtheiro is not originally found in the parable, the idea could be traced in the story. Phtheiro refers to the physical decay of the human body and metonymy for anything which is liable to corruption. It also refers ethnically to the physical gratification of evil desires and lust (Vine, 1996,131). In the Greco-Roman world where this manager in the parable was situated, the society depended greatly on the wealthy individual who provided for others who could be referred to as benefactors (euergetes) (Walker 2000,157). Here in this parable, the debtors of the kurios became euergetes of the oikonomon overnight. We can call this the power of manipulation. Moreover, there was a vast disparity between the income of the poor in the world of this rich master and his estate manager. For instance, a wealthy estate owner like the rich man in this parable had more than seven hundred times the income of a peasant, and the extremely wealthy might have more than fifteen thousand times the income of a peasant (Keener 2000,353; Bastomsky 1990,37-43).

Moreover, the concept of pistis is also present in the parable (vv.9-12) and it means faith, fidelity, trust or faithfulness (Summers 1995,180). While pisitis means faith in God through Jesus Christ for Salvation of the human soul on the one hand, it also means the soundness 
of the mind in keeping faith or being faithful in all that one does. Another word used that can be used complementarily with pistis or pistoi (faithfulness) is dikaois and it means a state of being righteous or just (Summers 1995,175). Righteousness has to do with doing what is right in the sight of God and man. It is even stated elsewhere in the Old Testament (Prov. 14:34) that: "Righteousness exalts a nation but sin or wrong doings is a reproach to a nation and even the people. The master expected faithfulness from the manager in the affairs of administration of his resources not the other way round. This is a wake up call to all leaderships in sacred and secular spheres of the society to be awake to faithfulness in their administration of human and material resources.

The concept of mamona (mammon) also came up in the periscope and it means wealth and riches considered as an evil and corrupt influence (Encarta Dictionary 2008). According to Broomall (2004,337-338) the word mamona represents the Aramaic word for riches or wealth and the Christian understanding of mammon in Luke 16:9 is synonymous with the evil of money. In the Aramaic Targums mammon is used for ill wealth or gain. Although, in the New Testament usage, Paul used it, the word is confined to Jesus' teachings in the gospels (Matt.6:24; Luke 16:9,11,13). In Luke 16:9-13, mamona is used to expose the unrighteousness and unfaithfulness of the steward. By implication, if the disciples or a leader cannot manage little resources, one cannot expect much resources to be entrusted in the hand of such disciple or leader. It is morally impossible for one to serve God and 
mammon simultaneously like the greedy monopolizers and exploiters of economic wealth in Jesus' time (vv.1415). The demonstration of their love for their wealth may have made Jesus to make the statement: "you cannot serve God and mammon."

\section{Implications of Luke 16:1-15 for Nigerian Leaders}

The term 'Nigerian leaders' as used here, refer to leaders in both sacred and secular institutions in Nigeria. Although, the lesson so leant is intended to discourage corruption from the Nigerian society, leaders are more in focus here because they are the drivers of economic, political, religious and social spheres of the nation. Hence some vital lessons can be deduced from the passage (Luke 16:1-16) for contemporary Nigerian leaders.

i. Proper Management of Resources (v.1): The Greek word oikonomos in verse one gives the understanding of management. In this case, there was a report of mismanagement of resources on the part of the manager. He was placed in a position to manage some resources for his master but failed to manage it well. The report that got to the master was that of wastage of resources. This could be likened to misappropriation or squandering of resources in Nigeria today. That the master's attention was drawn to it and the actions that followed showed that resources should be properly managed. If the manager had properly managed the resources of his master well there would not have been any need to 
compile negative report indicting him of mismanagement. Being that owner frowned it, it suggests that the owner expected proper management of his resources not the other way round. This is the hiding lesson the reader is expected to learn. This resonate with report of financial misappropriations and wasteful spending we see today about Nigerian leaders. The lesson that Nigerian leaders must learn hear is to learn how to properly manage the nation's resources in such way the masses will be satisfied.

ii. Consciousness of Accountability (v.2). The phrase 'to give account' (logariasmós) in verse two denote the understanding of accountability. When the master of the manager heard the report of mismanagement he called on his manager to give a proper account of the business and the proceeds from the business. The owner of the business threatened to sack him if he cannot give proper account of all the resources he was given to manage. Being that the manager was conscious of accountability at this point in time he decided to manipulate to meet up. Nigerian leaders lack the consciousness of accountability that is probably why they manage Nigeria's resources with recklessness. They need to be accountable to people they are leading. The lesson Nigerian leaders (secular and sacred) must learn here is the consciousness of accountability in the management of State and church resources respectively. When Nigerian leaders have 
accountability at the back of their minds they would be mindful of how they manage the nations resources on behalf of the people.

iii. Fidelity and Honesty (vv. 3-12): The main theme in verses three to twelve if faithfulness (pistis) or honesty. Here in the passage, the manager displayed unfaithfulness. After the narration of how the manager manipulated the master's debtors to make up for his lapses, the lesson was later given in verse eleven to twelve. The paradox of shrewdness and unfaithfulness obscures the lesson from the hearer but the emphasis of entrusting more resources to some one who is faithful in the management of little depict the message of fidelity. The antics of the steward was a clear show of dishonesty. The attitude of the shrew steward is a prototype of some Nigerian religious, political, civic and traditional leaders. The act of honesty is also a lesson Nigerian leaders must learn not fail to learn here.

iv. Discouragement of Greed (vv.13-15). Luke tells us here that excessive cravings for money or material (philargyros) was discouraged in Jesus' community. The Pharisees ridiculed (exemykterizon) Jesus for discouraging human lust for money. The issue of greed has a parallel reading in 1Timothy $6: 10$ and 2 Timothy $3: 2$ and it was condemned with the proverbial saying: "the love of money is the root of all evil." By implication, the master in the parable does not care how money is made all he wants is money. 
This was why the master in the parable commended the shrewd steward who manipulated his way to make money for him. This scenario is not far fetched in Nigeria where it is a common place to see greedy rich men and women who sponsor criminality in Nigeria for the gain of money and power. Some people in Nigeria have been socialized into the world of mammon and as such the love for money routinely destroys our nation. Money has become an object of worship in Nigeria toady. Some leaders and even many people in the street of Nigeria are ready to do anything including evil just to make money. Many Nigerians have allowed their greed for money to drag their reputations down the drain. The lesson leaders must here is to discourage greed. The leaders should lead by example and encourage their followers to do same. Leaders should not be greedy and should discourage followers from being greedy.

\section{Conclusion}

Material and human resources play a vital in the development of an organization and even a nation. This passage (Luke 16:1-15) has dwelt on management of resources by leaders. It Discouraged leaders from mismanagement of resources. The immediate setting of the parable in Luke 16:1-15 include Semitic and Hellenistic audience who were familiar with the situation of corruption in their society. Such type of corruption 
manifested itself in greed and unfaithfulness. This Palestinian scenario being portrayed in the narrative resonates with the Nigerian situation of corruption. This is applicable to those who are given the priviledge to manage resources either on behalf of the state, religious body and even business owners but are mismanaging such resources for personal gain.

Nigerian leaders are being challenged here to imbibe the culture of: proper management of cooperate resources at their disposal; accountability; fidelity and honesty; abhorring of Greed. When all of these lessons are applied in Nigeria, it will compel Nigerian leaders in sphere of leadership to be prudent and patriotic in the management of Nigeria's resources and as such, it will help to fight corruption in Nigeria.

John Arierhi Ottuh is of the

Winners Baptist Church Effurun,

Delta State, Nigeria. 


\section{References}

Achebe, C. 1983. The Trouble with Nigeria. Enugu: Fourth Dimension Publishers.

Apenda, A.Z. 2006. Spirituality or Materialism: The Dilemma of Contemporary Church in Nigeria. In M.T. Yahya, A.P.Dopamu, R.A. Odumuyiwa, E.A. Shishima, S.A. Owoeye, and P.O.Abioje (eds) Issues in the Practice of Religion in Nigeria. Jos: Nigerian Association for the Study, 125-139.

Ayobami, O.O. 2011. Corruption Eradication in Nigeria: An Appraisal. Library Philosophy and Practice, (online) available: http://unllib.unl.edu/LPP/ (February 11, 2013.

Bailey, K. 1983. Poet and Peasant: A Literary-Critical Approach to the Parable in Luke. Grand Rapids: Eerdmans.

Bailey, K.E. 1993. The Oxford Companion to the Bible. New York: Oxford University Press.

Bastomsky, S.J. 1990. Rich and Poor: The Great Divide in the Ancient Rome and Victorian England. $G R$ 37:37-43.

Broomall, W. 2004. Mammon. In E.F.Harrison, G.W. Bromiley and C.F.Henry (eds.) Wycliffe 
Dictionary of Theology. Peabody, Massachusetts: Hendrickson Publishers, Inc.

Carter, W. 2002. Resisting and Imitating the Empire: Imperial Paradigms in Two Matthean Parables, Interpretation: A Journal of Bible and Theology 56 (3):261-262.

Complete Christian Dictionary for Home, School and Office. 2002. USA: Oasis International Ltd.

Crossan, J. D. 2002. The Parables of Jesus, Interpretation. A Journal of Bible and Theology 56(3): $247-259$.

Dillard, J.E. 1953. Good Stewardship. Nashville, Tennessee: Broadman Press.

Encarta Dictionary (2008). Microsoft online Encarta Dictionary inc.

Egbo, S. H. O. 2010. Deregulation of The Downstream Sector of The Nigeria Oil and Gas Industry: Prospect and Challenges. Being an Unpublished Paper Presented at the 2010 Pre-graduation Lecture of Petroleum Training Institute, Effurun Held on April 22, 35pp.

Faloore, O.O. 2012. Political Corruption and Poverty in Nigeria. African Journal for the Psychological Study of Social Issues 12 (1-2): 1-12. 
Folarin, G.O. 2006. The Parable of the Talents in African Context: The Approach of Inculturation Hermeneutics. In J.S.Ukpong (ed) African Biblical Interpretation: A Reader. Unpublished Lecture Note, University of Uyo, 24-29.

Foster, L.1995. Luke. In K.L.Barker, D.W.Burdick, J.H. Stek, W.W.Wessel and R. Youngblood (eds) The NIV Study Bible. Grand Rapids: Zondervan Publishing House, 1529-1587.

Gbenda, Joseph S. 2006. Marketting God in Nigeria: A Critique of Nigerian Independent Churches. In M.T. Yahya, A.P.Dopamu, R.A. Odumuyiwa, E.A. Shishima, S.A. Owoeye, and P.O.Abioje (eds) Issues in the Practice of Religion in Nigeria. Jos: Nigerian Association for the Study, 117-124.

Harris, R. L. and Youngblood, R.1995. Leviticus. In: K.L. Barker, D.W.Burdick, J.H. Stek, W.W.Wessel and R. Youngblood (eds) The NIV Study Bible. Grand Rapids: Zondervan Publishing House, 144-182.

Herzog, W.1994. Parables as Subversive Speech: Jesus as Pedagogue of Oppressed. Louisville: Westminster John Knox.

Houdmann, Michael S. 2013. What is Biblical Stewardship? (Online) available: 
http://www.gotquestions.org/biblicalstewardship. html, accessed May 19,2014.

Iroegbu, P. 1995. The Rise / Spread of Religious Sects in Nigeria and the Socio-Economic situation in the country. The Portraits. 5 (1): 19-34.

Julicher, A. 1910. Die Gleichnisreden Jesu. Tubingen: Mohr, 2:495.

Keener, C.S. 2000. Family and Household. In C.A. Evans and S.E Porter (eds) Dictionary of the New Testament Background. Downer Grove, Illinois: InterVarsity Press, 353-368.

Kehlenberger, J.R. 1987. The Interlinear NIV HebrewEnglish Old Testament. Grand Rapids: Zondervan Publishing House.

Lenski, Richard Charles H. 2008. Interpretation of St. Luke's Gospel, Chapters 12-24, Vol 2. Fortress Press.

Lunt, R.G. 1954. Towards an Interpretation of the Parable of the Unjust Steward (Luke xvi.1-18). Expository Times 66:335.

Malina, B. and Rohrbaugh, R.1992. Social-Science Commentary on the Synoptic Gospels. Philadelphia: Fortress. 
Myers, C. 2012. From Capital to Community: Discipleship as Defection in Jesus' Parable about a Manager of Injustice (Luke 16:1-13). In Z. Bannett, and D.B.Gowler (eds) Radical Christian Voices and Practice: Essays in Honour of Christopher Roland. New York: Oxford University Press, 51-68.

Oakman, D.E. 2000. Economics of Palestine. In C.A. Evans and S.E.Porter (eds) Dictionary of the New Testament Background. Downer Grove, Illinois: InterVarsity Press, 303-308.

Obienyem, V. C. 1999. But Whither Christianity? The Torch. 117: June-December.

Odey, John O. 2001. The Anti-Corruption Crusade: The Saga of a Crippled Giant. Enugu: Snaap Press Ltd.

Oladele, K. 2014. Political Corruption and Governance Problems in Nigeria: Understanding the Critical Issues. Sahara Reporters, (Online) available: http://saharareporters.com/article/politicalcorruption-and- governance-problemsnigeria- understanding-critical-issueskayode-ol, accessed May 23, 2014

Oxford dictionary of the English Language. 2013. Oxford University Press. 
Rucker, A. 1912. Uber das Gleichnis vom ungerechten Verwalter, Lc 16:1-13. BibS(F) 17:1.

Stoll, R. 1941. The Unjust Steward-A Problem in Interpretation. Ecclesiastical Review 105:17.

Summers, R. 1995. Essentials of New Testament Greek. Nashville, Tennessee: Broadman and Holman Publishers.

Tenney, Merrill C. 1961. New Testament Survey. Grand Rapids: Wm B. $\quad$ Eerdmans Publishing Co.

Thayer, J.H. 2011. Thayer's Greek Lexicon, Electronic Database. BibleSoft.com. Biblesoft, Inc.

Ughegbe, L. and Onyekwere, J. 2013. Outrage as Pension Funds. Fraudster Get Two- Year Sentence. The Guardian. Tuesday 29 (12) 451: 1 and 6.

Ukoni, U. D. 2010. Nigeria. Search of Credible Leadership: A Reflection of 50 Years of Nigeria as an Independent Nation. Makurdi: Book Makers Publishing.

Ukpong, Justin S. 1996. The parable of the Shrewd Manager (Luke 16:1-13): An Essay in Inculturation Biblical Hermeneutics. Semeia, 189-210. 
Vine, W. E. 1996. Vine's Complete Expository Dictionary of Old and New Testament Word. Nashville: Thomas Nelson Publishers.

Walker, D.D. 2000. Benefactor. In C.A. Evans and S.E.Porter (eds) Dictionary of the New Testament Background. Downer Grove, Illinois: InterVarsity Press, 157-159.

Wessel, W.W. and Lane, W.L. 1995. Mark. In: K.L. Barker, D.W.Burdick, J.H. Stek, W.W. Wessel and R. Youngblood (eds) The NIV Study Bible. Grand Rapids: Zondervan Publishing House, 1488-1528. 